\title{
УДК: 378.018.43:004
}

\section{Руснак Ірина Євгеніївна}

доктор філологічних наук, професор, директорка Інституту філології

Київський університет імені Бориса Грінченка, м. Київ, Україна

ORCID ID 0000-0001-8355-7389

i.rusnak@kubg.edu.ua

\section{Саврасова-В'юн Тетяна Олександрівна}

кандидат психологічних наук, заступниця директора Інституту філології з науково-педагогічної та соціально-гуманітарної роботи Київський університет імені Бориса Грінченка, м. Київ, Україна

ORCID ID 0000-0001-5737-6189

t.savrasova-viun@kubg.edu.ua

\section{Заяць Людмила Іванівна}

кандидат педагогічних наук,

заступниця директора Інституту філології з науково-методичної та навчальної роботи

Київський університет імені Бориса Грінченка, м. Київ, Україна

ORCID ID 0000-0003-1751-1301

l.zaiats@kubg.edu.ua

\section{Доценко Олена Леонідівна}

кандидат філологічних наук, доцент,

заступниця директора Інституту філології з наукової роботи і міжнародних проєктів

Київський університет імені Бориса Грінченка, м. Київ, Україна

ORCID ID 0000-0003-4607-0883

o.dotsenko@kubg.edu.ua

\section{ВПЛИВ ВІРТУАЛЬНОГО ОСВІТНЬОГО ПРОСТОРУ НА СТРЕСОСТІЙКІСТЬ МАЙБУТНІХ ФІЛОЛОГІВ}

\begin{abstract}
Анотація. У статті висвітлено актуальну проблему впливу сучасного віртуального освітнього простору на стресостійкість майбутніх філологів класичного університету. Наголошено, що в умовах невідкладного запровадження в системі освіти карантинного режиму і переходу на дистанційну форму навчання, опанування віртуального освітнього простору стало першочерговим завданням не лише для професорсько-викладацького складу вищого освітнього закладу, але й для майбутніх фахівців. Описано досвід організації віртуального освітнього середовища із застосуванням засобів дистанційного навчання на базі Інституту філології Київського університету імені Бориса Грінченка та їх вплив на стресостійкість майбутніх філологів. Зазначено, що завдяки віртуальному освітньому простору Інституту майбутні філологи опановують навички практичного застосування мови в професійному, ситуативному спілкуванні, формують новий підхід до методики навчання мови і літератури, мають змогу інтегрувати засоби ІКТ у майбутню професійну діяльність. Визначено зміст, структуру стресостійкості майбутніх фахівців, дібрано методичний інструментарій дослідження рівня стресостійкості студентів. Актуальність теми підтверджена наведеними результатами опитування майбутніх філологів, які проходили діагностику з проблеми вивчення рівня стресостійкості як за умов традиційної форми навчання, так i в режимі дистанційного навчання. В експерименті взяли участь 214 студентів спеціальності 035 «Філологія». Шляхом експериментальної діяльності виокремлено особливості впливу віртуального освітнього простору на стресостійкість майбутніх філологів. Виявлено, що рівень стресостійкості майбутніх філологів за умов традиційного навчання вищий, ніж рівень стресостійкості студентів в умовах надмірного перебування у віртуальному освітньму просторі. Запропоновано альтернативне рішення: реально-віртуальний освітній простір як змінне середовище, у якому суб'єкти простору можуть керувати освітніми ситуаціями. Зазначено рекомендації з розвитку стресостійкості майбутніх філологів в умовах реально-віртуального освітнього простору.
\end{abstract}


Ключові слова: віртуальний освітній простір; дистанційна форма навчання; онлайн навчання; інформаційно-комунікаційні технології; реально-віртуальний освітній простір; стресостійкість майбутніх філологів.

\section{1. ВСТУП}

Постановка проблеми. Сучасний інтенсивний ритм життя людей призводить до накопичення негативних емоцій, стресових станів. У цьому процесі важливу роль відіграє стресостійкість особистості, яка дає змогу уникати стресу за допомогою перегляду ставлення до ситуації. Стресостійка людина за будь-яких умов спокійна, впевнена в собі, самодостатня, здатна виконувати поставлені завдання. Завдяки розвиненій стресостійкості особистість має міцне здоров'я, запобігає появі значної кількості захворювань. Зростання кількості стресостійких особистостей - запорука здорової нації та міцної держави. До того ж на сучасному етапі розвитку суспільства провідною тенденцією вищої освіти $\epsilon$ становлення професійно компетентного, ініціативного, відповідального громадянина, який здатний адаптуватись до умов сьогодення, готовий до неперервного опанування зростаючого обсягу інформаційних потоків, спроможний розширювати і поглиблювати наукову сферу. 3 року в рік вимоги до особистісних якостей майбутніх фахівців неухильно зростають. Однак варто пам'ятати, що однією з вразливих груп населення, яка гостро реагує на будь-які трансформації в суспільстві, $є$ студенти. Саме вони найчастіше піддаються інтелектуальним випробуванням, намагаються поєднувати навчання і роботу, шукають своє місце у світі, вирішують проблеми в умовах змін, формують моделі взаємовідносин з освітнім середовищем, визначають власні цінності та принципи, прилаштовуються до різних побутових умов життя, навчаються організовувати i регулювати власну життєву траєкторію, набувають професійних компетентностей тощо [1], [2].

Представлені основи життєдіяльності майбутніх фахівців, запити споживачів освітніх послуг зумовлюють характер освітнього простору навчального закладу, який, зокрема, є основним чинником формування і розвитку особистості. Адже освітній простір виступає як площина, де здійснюються комунікативні взаємозв'язки, реалізується діяльність різних систем, що визначають становлення особистості, розкриття ïi потенціалу [3].

Крім того, запити суспільства обумовлюють появу нових технологічних інформаційно-комунікаційних розробок, які допомагають швидко й ефективно вирішувати інтеграційні, інформаційні, комунікаційні, економічні проблеми соціуму, забезпечують нові продуктивні можливості опрацювання електронних даних. Так, останнім часом помітного поширення набули засоби інформаційних технологій нового покоління (iPAD, imPad, iPadHibrid, Reder, iPhone, SmartPhone, iPod, мультимедійні дошки з Інтернет-доступом тощо), які вирізняються швидкодією, мобільністю, обсягом пам'яті; мобільні інтернет-пристрої (Mobil Internet Device, Internet-Gadgets), що мають довготривале автономне енергозабезпечення, малі масогабаритні параметри; широкий спектр засобів під'єднання до комп'ютерних, аудіо-, відеозасобів, засобів друку; систематично оновлюване програмне забезпечення; різноманітні засоби телекомунікаційного зв'язку (Google Meet, Viber, ZOOM, Webex meeting, Messenger, Skype, Telegram, WhatsApp); соціальні мережі (блог-системи, YouTube, Facebook, Instagram, Twitter); сервіс публікації фотографій, медіасховища та інші. 3 появою інформаційно-комунікаційних інновацій змінюється й освітній простір, набуваючи іншого сенсу і змісту. Під час прискореного розвитку інформаційно-комунікаційних 
технологій освітній простір розбудовується у віртуальній реальності, реалізуючись через дистанційне навчання.

Немає сумніву, що таке навчання привабливе економічною вигодою, рентабельністю, зручністю, доступністю та безперервністю [4]. Проте практичний досвід масового застосування дистанційного навчання в період невідкладного запровадження у систему освіти карантинного режиму виявив низку психологічних, валеологічних, педагогічних і технологічних труднощів в організації гармонійного, безпечного освітнього простору. Крім того, викликає занепокоєння рівень тривоги, емоційної напруги майбутніх фахівців, породжений автономними умовами навчання в оточенні віртуального світу [5]. Тому постає достатньо актуальна проблема ретельного дослідження особливостей безперервного впливу віртуального освітнього простору на стресостійкість майбутніх фахівців, які навіть в умовах реального світу є чутливими і вразливими до будь-яких змін. Особливої ваги набуває запропоноване дослідження в контексті застосування різних форм дистанційної освіти, зокрема цифрових методів організації навчального процесу, в інклюзивних практиках, які, вочевидь, будуть використовувати онлайнові платформи і після пандемії. А робота 3 цією категорією здобувачів освіти потребує максимальної уваги з боку психологів і соціальних працівників, оскільки саме люди 3 особливии потребами, зокрема й освітніми, залишаються найменш захищеними в Україні.

Аналіз останніх досліджень і публікацій. Проблема освітнього простору цікавить багатьох науковців, зокрема L. Darling-Hammond [6]; Н. Рибку [7]; Т. Ткача [8]; А. Цимбалару [9] та інших. Фахівці визначають сутність, структуру, риси продуктивності, шляхи формування досліджуваного феномена. Освітній простір представлено як педагогічну реальність, у якій особистість взаємодіє, осмислює, пізнає освітнє середовище. Основними шляхами формування освітнього простору належать ергодизайн, конструювання, розгортання, самоорганізацію і проєктування [9].

Чимало праць присвячено різним аспектам застосування інформаційнокомунікаційних технологій в освіті (В. Биков [10]; Н. Морзе [11]; А. НашинецьНаумова [12]; K. Ratheeswari [13]; Г. Швачич [14] та інші). Зокрема науковців цікавлять цифрові інноваційні освітні технології активізації пізнавальної діяльності школярів [15], застосування мобільних додатків для оптимізації навчального процесу та контролю знань студентів [16]. Особливий інтерес викликають у педагогів-практиків дослідження емоційних станів учителів та учнів, викладачів і студентів у період пандемії COVID-19, коли освітній процес зорганізований 3 використанням електронного ресурсу. Про це, зокрема, пишуть Е. Помиткін, Л. Помиткіна та О. Іванова [17]. Важливими у цьому контексті є результати дослідження О. Кучерук, С. Карамана та О. Караман [18], Н. Віннікової [19] щодо застосування інформаційнокомунікаційних технологій для формування фахових компетентностей майбутніх філологів. Науковці зауважують, що в системі фахових компетентностей філологів доцільно виокремити дві групи: предметно-галузеві компетентності (сукупність знань, умінь, здатностей, ставлень, цінностей у межах змісту конкретного предмета, досвіду, необхідного для розв'язання освітніх проблем, завдань, ситуацій у контексті навчання філології); методичні компетентності (сукупність знань, умінь, здатностей, досвіду, ставлень, цінностей, пов'язаних з методикою навчання фахових дисциплін). Завдяки зазначеним компетентностям майбутній філолог може користуватися професійною мовою предметної галузі знань «мови і літератури», демонструвати вміння ефективно розв'язувати конкретні методичні завдання професійної діяльності, застосовувати сучасні інформаційно-комунікаційні технології тощо. Однак, як зазначають дослідники, підготовка студентів-філологів до використання інформаційно-комунікаційних технологій потребує грунтовного вдосконалення. За результатами дослідження 
фахівців, лише п'ята частина майбутніх філологів постійно використовує під час навчання фахових дисциплін електронні ресурси; більше половини респондентів нечасто застосовують такі ресурси в навчальній діяльності, адже усвідомлюють відсутність належного рівня компетентності у використанні інформаційнокомунікаційних технологій. Як наслідок, десята частина майбутніх філологів відчуває розгубленість, внутрішній неспокій, занепокоєння. Дослідники також виокремлюють види діяльності студентів із використання електронних ресурсів, які ефективно впливають на фахову підготовку майбутніх філологів (розроблення віртуальних тренажерів, створення комп’ютерних презентацій та інші) [18]; [19].

На особливу увагу заслуговують дослідження Л. Лук'янової [20], Г. Сотської [20], Г. Товканець [20], О. Тринус [20] та інших учених, що спрямовані на визначення сутності та особливостей віртуального освітнього простору, де головними напрямками наукового пошуку постають питання змісту, переваг, недоліків зазначеного явища, формату впровадження.

Висвітленню проблем стресостійкості присвячені праці I. Chamine, B. Oken, W. Wakeland [21]; G. Essel, P. Owusu [22]; S. Hobfoll [23]; Н. Лебідь [24] та інших дослідників. Зокрема I. Chamine, B. Oken and W. Wakeland зазначають, що стресостійкість - це здатність людини долати вплив значущих зовнішніх стресорів, коли організм досягає оптимально стабільного стану за допомогою витрат потенціалу задля мінімізації шкідливих наслідків для організму [21, с. 150].

Продуктивними для цього дослідження є праці О. Вознюк [25]; M. Carroll-Mayer, B. Marcinkowski, M. Płotka [26]; C. Семчук [27] та інших, де осмислено питання впливу віртуального освітнього простору на процес становлення особистості. Науковці визначили низку проблем у розвитку молодого покоління, пов'язаних 3 безконтрольним, безмежним перебуванням особистості у віртуальному світі, акцентуючи увагу на вдосконаленні процедури впровадження інформаційнокомунікаційних технологій в освітню галузь задля конструктивного вирішення конфлікту інтересів здобувачів освіти.

Однак проблема особливостей впливу надмірного перебування у віртуальному освітньому просторі на стресостійкість майбутніх філологів під час оволодіння професійними компетентностями залишається недостатньо розкритою.

Мета статті - охарактеризувати сутність і специфіку віртуального освітнього простору, стресостійкості особистості в умовах цифрової освітньої комунікації; експериментально дослідити та обгрунтувати особливості надмірного впливу віртуального освітнього простору на стресостійкість майбутніх філологів; схарактеризувати реально-віртуальний освітній простір як змінне середовище, у якому суб'єкти простору можуть керувати освітніми ситуаціями.

\section{2. ТЕОРЕТИЧНІ ОСНОВИ ДОСЛІДЖЕННЯ}

Освітній простір як феномен став предметом наукових розвідок педагогів ще у 80х роках XX століття. Сьогодні термін «освітній простір» перебуває у центрі уваги не лише педагогів, але й психологів, філософів, соціологів. Адже, згідно з дослідженнями А. Цимбалару [9], термін «освітній простір» має два аспекти потрактування: інституційний та індивідуальний. 3 огляду на інституційний підхід освітній простір розглядають як частку соціуму, де створені умови для розвитку особистості, здійснюється нормована освітня діяльність, реалізуються соціальні зв'язки. У межах індивідуального підходу освітній простір визначає можливості формування особистісного простору учасників освітнього процесу. Автор виокремлює структурні компоненти освітнього простору, зокрема середовище (інформаційне, соціальне, 
внутрішнє), освітню програму, освітні завдання, взаємодію вчителя, учня і середовища $[9$, c. 43$]$.

L. Darling-Hammond зауважує, що продуктивний освітній простір сприяє не лише успішному формуванню вмінь, навичок тих, хто навчається, але й гармонійному розвитку якостей і властивостей особистості. Серед основних рис продуктивності освітнього простору дослідник виокремлює позитивні стійкі відносини між учасниками освітнього процесу; фізичну, емоційну безпеку; якісні навчальні програми, стратегії викладання, оцінювання; опору на попередній досвід, знання тощо [6, с. 138].

3 огляду на те, що життєдіяльність сучасного суспільства стрімко вдосконалюється за рахунок використання інформаційно-комунікаційних технологій, які розглядаються як сукупність методів, процесів, програмно-технічних засобів, налаштованих на збирання, оброблення й застосування даних [14, с. 7], зміни відбуваються і в змісті освітнього простору, який все частіше курсує в напрямку віртуальної реальності [28, с. 234].

У дослідженнях Ю. Трач зазначено, що віртуальний освітній простір характеризується як засноване на застосуванні комп'ютерної техніки середовище, яке забезпечує учасників освітнього процесу інформаційними матеріалами за допомогою технологічних інструментів, змістового наповнення. Такий простір, де основними суб' єктами виступають студент, викладач, методист і технічний адміністратор, містить організаційно-методичні умови, сукупність технічних, програмних засобів зберігання, оброблення та передавання інформації [29, с. 168].

Віртуальний освітній простір, як підкреслюють В. Климнюк, М. Смульсон, може впроваджуватись у різноманітних форматах, серед яких переважають такі:

- денна (очна) освіта (передача емпіричного матеріалу через віртуальну реальність в семантичному навчанні);

- дистанційна освіта (навчання відбувається повністю 3 використанням Інтернету);

- змішана освіта (можливість віддалено знаходитися в аудиторії, взаємодіяти 3 реальними учасниками освітнього процесу);

- комбінована освіта (поєднання традиційної очної освіти та онлайн навчання);

- самоосвіта (самостійне вивчення матеріалу за допомогою Інтернет-ресурсів) [30, c. 209], [31, c. 12].

Ю. Трач виокремлює переваги і недоліки віртуального освітнього простору. Серед переваг дослідник зазначає безперебійне підключення, економію часу, фінансову економію, гнучкість, легке відстеження матеріалу та оцінки, необмежений доступ до інформації, персоналізацію, можливість самостійно регулювати темп навчання, наочність, безпеку тощо. До основних недоліків віртуального освітнього простору фахівець зараховує дезорієнтацію в матеріалі, зниження концентрації уваги, дискомфорт від технологій, відсутність емоційного контакту між людьми, відтворення лише тієї інформації, яка є в комп'ютерному середовищі, втрату освітою аксіологічних, екзистенційно значущих характеристик, випромінювання, залежність від технічної підтримки, наявності технічного пристрою та підключення до Інтернет-мережі, появу відчуття ізольованості, інформаційне перевантаження, відсутність менторської підтримки, дефіцит практичного досвіду. Віртуальний освітній простір вимагає високого рівня самоорганізації та самоконтролю [29, с. 170].

Варто зауважити, що представлені недоліки перебування у віртуальному освітньому просторі особливо гостро проявляються в умовах різкого переходу навчання 3 формату традиційної очної освіти на дистанційну, коли всі види освітньої діяльності перемістились у віртуальний світ, спричиняючи тим самим надлишкове знаходження учасників освітнього процесу у віртуальній реальності. Прикладом такої 
ситуації можна вважати невідкладне запровадження в закладах освіти дистанційного навчання в період карантинного режиму через вірусну пандемію. Наслідками таких недоліків, згідно зі спостереженнями С. Семчук, можуть бути валеологічні, психологічні та педагогічні проблеми, що супроводжуються високим рівнем психічного навантаження, емоційної напруги, низьким ступенем стресостійкості учасників освітнього процесу [27, с. 323].

На думку Н. Лебідь, завдяки стресостійкості особистість активізує спроможність соціально адаптуватися, зберігати міжособистісні стосунки, успішно самореалізовуватися, досягати цілей, бути працездатною і здоровою [24].

S. Hobfoll переконує, що стресостійкість грунтується на внутрішніх і зовнішніх peсурсах. До внутрішніх ресурсів стресостійкості автор зараховує особистісні (активну мотивацію подолання стрес-факторів, інтернальний локус контролю, впевненість у собі, позитивне, раціональне мислення, емоційний інтелект, досвід подолання стресових ситуацій, уміння звернутися за допомогою, навички психічної регуляції); поведінкові (копінг-стратегії, асертивну поведінку, пошук соціальної підтримки); фізичні (стан здоров'я, турботу про збереження, зміцнення здоров'я), стиль життя (наявність/відсутність шкідливих звичок, наявність часу для відпочинку, здорове харчування, сон). Серед зовнішніх ресурсів стресостійкості дослідник виокремлює соціальну підтримку (інститути соціальної підтримки, державу, організацію, родину, друзів), матеріальні ресурси (достатній рівень матеріального прибутку, задовільні умови життя, відпочинку, безпека життя, оптимальні умови праці) [23]. Однак, як стверджують G. Essel, P. Owusu, не завжди ресурси допомагають майбутнім фахівцям підтримувати достатній рівень стресостійкості; є чинники, які доволі часто підривають репутацію зазначеної властивості особистості. 3-поміж найбільш впливових чинників науковці називають відсутність відпочинку, незадовільні умови життя, страх, майбутні турботи, фінансові проблеми, нереальні очікування, академічний тиск, конфлікти, почуття безпорадності, залежності, проблеми з комп'ютером тощо [22].

Грунтуючись на результатах наукових пошуків О. Вознюк [25], В. Marcinkowski [26], Т. Oppenheimer [32], С. Семчук [27], які розкривають особливості впливу цифрового середовища на становлення особистості, вважаємо за необхідне зарахувати надмірне перебування у віртуальному освітньому просторі до чинників, що впливають на рівень стресостійкості майбутніх фахівців, i перевірити це припущення експериментально.

\section{3. МЕТОДИКА ДОСЛІДЖЕННЯ}

Для досягнення мети статті було застосовано теоретичні, емпіричні методи наукового дослідження. Серед теоретичних методів використано аналіз, опис сучасного стану досліджуваної проблеми, узагальнення теоретичних підходів стосовно розуміння основних термінів. До емпіричних методів зараховано опитування, застосоване для вивчення рівня складників стресостійкості майбутніх філологів (когнітивного (показник: конфліктологічна компетентність), мотиваційного (показники: прагнення досягти життєву мету, готовність до змін), емоційного (показники: емоційна стабільність, тривожність, ставлення до себе), діяльнісного (показник: уміння адаптуватися), порівняльного), кореляційний аналіз, статистичні методи оброблення результатів дослідження. Для визначення рівня стресостійкості майбутніх філологів було використано валідні, надійні діагностичні методики, а саме:

- методика «Оцінка рівня компетентності у вирішенні конфліктів» спрямована на вивчення рівня конфліктологічної компетентності майбутніх філологів; 
- методика «Мотивація азарту» застосована для дослідження рівня прагнення студентів досягти життєву мету;

- опитувальник «Визначення нервово-психічної напруги» уможливлює вивчення рівня готовності до змін респондентів;

- методика «Шкала емоційної стабільності - нестабільності» Г. Айзенка передбачає дослідження рівня емоційної стабільності майбутніх фахівців;

- шкала реактивної та особистісної тривожності Спілбергера-Ханіна спрямована на виявлення рівня тривожності студентів;

- методика «Самооцінка особистості» дає змогу дослідити рівень ставлення до себе майбутніх філологів;

- шкала психологічного стресу RSM-25 передбачає вивчення рівня вміння адаптації студентів.

Статистичне оброблення даних здійснювалось за допомогою пакета статистичних програм SPSS.

\section{4. РЕЗУЛЬТАТИ ДОСЛІДЖЕННЯ}

Аналіз наукової літератури дав змогу охарактеризувати віртуальний освітній простір Інституту філології Київського університету імені Бориса Грінченка як відкрите динамічне середовище застосування інформаційно-комунікаційних технологій задля ефективної реалізації освітнього процесу професійної підготовки філологів. Серед складових віртуального освітнього простору Інституту виокремлено суб'єкти простору; електронні ресурси; засоби електронної комунікації; форми організації освітнього процесу.

Основними суб'єктами віртуального освітнього простору Інституту філології виступають студенти, викладачі, методисти, помічники з інформаційно-комунікаційних технологій.

До ресурсів віртуального освітнього простору Інституту належать такі:

- електронні бібліотеки (навчальні підручники, посібники, віртуальні словники, енциклопедії, довідники, навчально-методичні журнали, збірники наукових праць, монографії);

- інституційний репозиторій [33];

- електронні навчальні курси (матеріали лекцій, навчально-методичні відеоролики, завдання для самостійного опрацювання, комп'ютерне тестування);

- сайт Київського університету імені Бориса Грінченка [34];

- спільноти у Facebook кафедри української літератури, компаративістики i грінченкознавства [35]; Центру перекладу (Translation Centre at Grinchenko University) [36]; Центру культури української мови [37]; кафедри романської філології та порівняльно-типологічного мовознавства [38]; По-літ [39]; кафедри східних мов і перекладу [40]; кафедри германської філології [41];

- ютуб-канали (Центру компетентностей «Літературний театр» [42]; Інституту філології [43]; кафедри світової літератури [44]; студентської ради Інституту філології [45];

- блог Центру культури української мови [46];

- Telegram-канали (Центру перекладу [47]; Центру культури української мови [48]; студентської ради Інституту філології [49];

- сторінки в Instagram (Інституту філології [50]; кафедри східних мов і перекладу [51] тощо). 
Засобами електронної комунікації у віртуальному освітньому просторі Інституту філології є корпоративна електронна пошта, засоби зв'язку (Viber, Telegram, Messenger, WhatsApp та інші), засоби телекомунікації (Google Meet, Viber, ZOOM, Webex meeting, Messenger, Skype, Telegram, WhatsApp), технічні засоби (комп'ютери, планшети, мобільні телефони, смартфони та інше).

Основними формами організації освітнього процесу у віртуальному просторі Інституту філології $\epsilon$ електронні навчальні курси, самостійна, проєктна робота 3 інформаційними джерелами через мережу Інтернет, поточний, семестровий контроль із застосуванням інформаційно-комунікаційних технологій, створення відеороликів, електронних портфоліо, комп’ютерні презентації, консультації, онлайн конференції, вебінари, онлайн конкурси, майстер-класи, онлайн квести, онлайн захисти наукових робіт тощо.

Завдяки віртуальному освітньому простору Інституту філології Київського університету імені Бориса Грінченка майбутні філологи оволодівають різними аспектами мови, опановують мовленнєві навички, уміння (читати, аудіювати, писати, говорити, перекладати), розвивають лінгвістичну, соціолінгвістичну, соціокультурну, прагматичну компетентності, навички практичного застосування мови в професійному, ситуативному спілкуванні в усній і письмовій формах, формують новий підхід до методик навчання мови і літератури, мають змогу інтегрувати засоби IКТ у майбутню професійну діяльність. Приналежність до віртуальних спільнот допомагає майбутнім філологам долучитися до проблеми популяризації культури країни, мова якої вивчається, брати участь у тематичних дискусіях, реалізовувати спільні освітні проєкти, ділитися цікавою інформацією, презентувати власні успіхи і досягнення під час оволодіння фаховими компетентностями тощо.

Віртуальний освітній простор Інституту філології за традиційним форматом навчання - явище періодичне, додаткове. Натомість традиційний (очний) формат здобуття освіти майбутніми фахівцями спеціальності 035 «Філологія» в Інституті філології Київського університету імені Бориса Грінченка передбачає безпосередню участь студентів в освітньому процесі. За такого формату навчання організація освітнього процесу забезпечується завдяки фіксованому регламенту, що містить чіткий перелік дисциплін, настановчі навчальні заняття (лекції, семінарські, практичні, модульні, консультації тощо), екзаменаційно-залікові сесії, міжсесійну роботу, практики, діяльність у центрах компетентностей, самостійну роботу тощо. Крім того, освітній процес розширює поле свого впливу на діяльність студентів у науковій сфері, що передбачає участь у міжнародних, усеукраїнських конференціях, конкурсах наукових робіт, олімпіадах і т.д. Доповнює список видів діяльності майбутніх філологів очної форми навчання і соціально-гуманітарна робота, що вирізняється різноманітними культурно-масовими заходами, благодійними проєктами, зустрічами 3 митцями, студентським самоврядуванням тощо. Віртуальний освітній простір у такому форматі допомагає майбутнім філологам навчитися бути мобільними, гнучкими, реалізовувати освітні цілі у різних життєвих умовах.

Під час пандемії освітній процес Інституту філології повністю перейшов у простір віртуальної реальності за дистанційною моделлю здобування освіти. Усі вищезазначені види освітньої діяльності студентів очної форми навчання були трансформовані та переведені у віртуальний освітній простір, що активізувало у майбутніх філологів здатність користуватися інформаційно-комунікаційними технологіями. До того ж студенти мали можливість підключатися до лекцій, практичних і семінарських занять, захистів дипломних робіт, конференцій, засідань, культурно-мистецьких заходів, встановлювати і підтримувати діалог з викладачами, кураторами, адміністрацією за допомогою різних засобів телекомунікації, продуктивно опановувати матеріал за 
електронними навчальними курсами, ознайомлюватись 3 усіма подіями, що транслювались на сайті Університету, у соціальних мережах. Однак до окреслених аспектів віртуального освітнього простору додавалося самостійне навчання майбутніх філологів 3 використанням сучасних технічних засобів трансляції інформації та технічно-організаційна робота із завантаження, оброблення, пересилання матеріалів, що значно збільшило час перебування студентів у віртуальній реальності.

Тому для виявлення особливостей впливу віртуального освітнього простору на стресостійкість майбутніх філологів за різних умов було проведено порівняльний аналіз емпіричних результатів дослідження складових стресостійкості майбутніх філологів у період оволодіння професійними компетентностями у форматі традиційного (очного) навчання, коли віртуальний освітній простір був періодичним явищем, та під час карантинного режиму, коли процес освіти відбувався дистанційно і віртуальний освітній простір був єдиним осередком реалізації завдань освіти.

3 метою здійснення аналізу і порівняння емпіричних даних стресостійкості майбутніх філологів до (I зріз у жовтні 2019 року) і під час карантинного режиму (II зріз у червні 2020 року) було проведено онлайн опитування студентів Інституту філології Київського університету імені Бориса Грінченка, у якому взяли участь 214 майбутніх фахівців спеціальності 035 «Філологія» 1-4 курсів.

Попередньо дослідження стресостійкості майбутніх філологів у жовтні 2019 року було проведено в межах вивчення проблеми лідерства студентів Інституту філології. Згодом отримані результати опитування щодо рівня стресостійкості майбутніх філологів стали в пригоді під час здійснення порівняльного аналізу даних досліджуваного явища карантинного періоду.

Аналіз результатів дослідження рівня складників стресостійкості майбутніх філологів у жовтні 2019 року за когнітивним, мотиваційним, емоційним, діяльнісним критеріями уможливив визначити високий, середній і низький рівні стресостійкості здобувачів освіти, які навчалися за традиційним форматом.

Рівень когнітивного складника стресостійкості майбутніх філологів проаналізовано на основі вивчення рівня показника «конфліктологічна компетентність».

У табл. 1 показано, що рівень когнітивного складника майбутніх філологів розвинений достатньо. Більшість студентів мають середній рівень $(52,8 \%)$, третина майбутніх фахівців $(33,6 \%)$ має високий рівень, із низьким рівнем досліджуваного явища - 13,6\% респондентів від загальної кількості опитаних.

Рівень мотиваційного складника стресостійкості майбутніх філологів проаналізовано на основі дослідження рівня показників «прагнення досягти життєвої мети», «готовність до змін».

Результати аналізу (табл. 1) свідчать про те, що високий рівень мотиваційного складника має більшість студентів $(50,9 \%)$, середній рівень досліджуваного явища притаманний третині опитаних $(39,7 \%)$, низький рівень мотиваційного складника мають 9,4\% респондентів.

За допомогою показників «емоційна стабільність», «тривожність», «ставлення до себе» проаналізовано рівень емоційного складника стресостійкості майбутніх філологів.

Дані дослідження емоційного складника (табл. 1) вказують на середній рівень його розвиненості в більшості майбутніх філологів (56,1\%). Низьким рівнем емоційного складника володіють $14,9 \%$ студентів, високий рівень мають $28,9 \%$ респондентів.

Рівень діяльнісного складника стресостійкості майбутніх філологів проаналізовано на основі вивчення рівня показника «вміння адаптуватися». 
Результати дослідження (табл. 1) показують, що середній рівень діяльнісного складника має більшість студентів (59,3\%), високий рівень притаманний 35,1\% опитаних, низький рівень діяльнісного складника мають 5,6\% респондентів.

Таблиия 1

Рівень складників стресостійкості майбутніх філологів в умовах традиційного формату навчання (у \%) станом на жовтень 2019 року

\begin{tabular}{|c|c|c|c|}
\hline $\begin{array}{c}\text { Складники } \\
\text { стресостійкості } \\
\text { майбутніх філологів }\end{array}$ & \multicolumn{3}{|c|}{$\begin{array}{c}\text { Рівень складників стресостійкості майбутніх філологів } \\
\text { (кількість респондентів у \%) }\end{array}$} \\
\cline { 2 - 4 } & Високий & Середній & Низький \\
\hline Когнітивний складник & 33,6 & 52,8 & 13,6 \\
\hline Мотиваційний складник & 50,9 & 39,7 & 9,4 \\
\hline Емоційний складник & 28,9 & 56,2 & 14,9 \\
\hline Діяльнісний складник & 35,1 & 59,3 & 5,6 \\
\hline Стресостійкість & 37,1 & 52,0 & 10,9 \\
\hline
\end{tabular}

Дані табл. 1 демонструють також загальний стан розвитку стресостійкості майбутніх філологів за I зрізом, а саме: високий рівень мають $37,1 \%$ студентів, середнім рівнем володіють 52,0\% респондентів, низький рівень стресостійкості мають $10,9 \%$ опитаних. Отримані результати свідчать про те, що за традиційним форматом навчання 3 періодичними елементами віртуального освітнього простору майбутні філологи мають достатньо розвинену стресостійкість.

Аналіз II зрізу результатів дослідження рівня складників стресостійкості майбутніх філологів надав можливість визначити рівень стресостійкості здобувачів освіти, які навчались у віртуальному освітньому просторі.

У табл. 2 вказано, що рівень конфліктологічної компетентності майбутніх філологів (когнітивний складник) розвинений недостатньо. 39,3\% студентів мають низький рівень когнітивного складника, більше третини майбутніх фахівців $(43,9 \%)$ має середній рівень, з високим рівнем досліджуваного феномена - 16,8 \% опитаних.

Результати аналізу (табл. 2) вказують на те, що середній рівень мотиваційного складника має більшість студентів $(53,3 \%)$, високий рівень досліджуваного явища притаманний 24,3\% опитаних, низький рівень мотиваційного складника мають 22,4\% респондентів.

Аналіз результатів дослідження емоційного складника (табл. 2) демонструє низький його рівень у $36,9 \%$ майбутніх філологів, 46,8\% студентів володіють середнім рівнем емоційного складника, високий рівень мають 16,3\% респондентів.

Результати дослідження діяльнісного складника (табл. 2) вказують на те, що середній рівень має 43,9\% студентів, низький рівень притаманний третині опитаних (38,7\%), високий рівень діяльнісного складника мають $17,7 \%$ респондентів.

Дані табл. 2 демонструють і загальний стан розвитку стресостійкості майбутніх філологів за II зрізом: високий рівень мають $18,8 \%$ студентів, середній рівень притаманний 46,9\% респондентам, $34,3 \%$ опитаних мають низький рівень стресостійкості. Отримані результати свідчать про те, що під час дистанційного навчання 3 ненормованим часом перебування у віртуальному освітньому просторі рівень стресостійкості майбутніх філологів знизився і став недостатнім для вирішення поточних завдань.

За допомогою статистичного оброблення отриманих результатів, зокрема критерію $\chi 2$, було з'ясовано значущі відмінності на рівні $(\rho<0,01)$ між показниками рівня стресостійкості майбутніх філологів I і II зрізів. 
На рис. 1 позначено, що кількість майбутніх філологів II зрізу з низьким рівнем стресостійкості збільшилась у порівнянні з I зрізом (з 10,9\% до 34,3\%), знизилася кількість студентів II зрізу з високим рівнем стресостійкості (з 37,1\% до 18.8\%) та знизилися відсоткові значення опитаних II зрізу із середнім рівнем стресостійкості (з $52,0 \%$ до 46,9\%). За критерієм знаків різниця між I і II зрізами є статистично значущою, що вказує на відповідні зміни рівня стресостійкості майбутніх філологів за різних умов застосування віртуального освітнього простору.

Таблиия 2

Рівень складників стресостійкості майбутніх філологів в умовах дистанційного формату навчання (у \%) станом на червень 2020 року

\begin{tabular}{|c|c|c|c|}
\hline $\begin{array}{c}\text { Складники } \\
\text { стресостійкості } \\
\text { майбутніх філологів }\end{array}$ & \multicolumn{3}{|c|}{$\begin{array}{c}\text { Рівень складників стресостійкості майбутніх філологів } \\
\text { (кількість респондентів у \%) }\end{array}$} \\
\cline { 2 - 4 } & Високий & Середній & Низький \\
\hline Когнітивний складник & 16,8 & 43,9 & 39,3 \\
\hline Мотиваційний складник & 24,3 & 53,3 & 22,4 \\
\hline Емоційний складник & 16,3 & 46,8 & 36,9 \\
\hline Діяльнісний складник & 17,7 & 43,9 & 38,7 \\
\hline Стресостійкість & 18,8 & 46,9 & 34,3 \\
\hline
\end{tabular}

Отримані результати чітко вказують на переваги i недоліки віртуального освітнього простору, основні причини змін у показниках стресостійкості майбутніх філологів.

Варто зазначити, що конфліктологічна компетентність як важливий складник стресостійкості особистості, що характеризує знання про конфлікти, уміння орієнтуватися в конфліктних ситуаціях, якісно розвивається під час очної взаємодії суб'єктів, які, демонструючи здатності до конструктивної дискусії, застосовують індивідуальний підхід до співрозмовника; у практичному застосуванні конфліктологічних знань в інтересах підвищення рівня раціональної поведінки в конфліктних ситуаціях; під час накопичення життєвого досвіду. Такі основи розвитку конфліктологічної компетентності можуть бути забезпечені в умовах традиційного (очного) формату освіти. На противагу цьому віртуальний освітній простір позбавлений живого спілкування i не здатний повністю реалізувати потребу особистості в емоційному контакті. Тому i показник когнітивного складника стресостійкості майбутніх філологів II зрізу нижчий за показник I зрізу.

При розгляді показника стресостійкості майбутніх філологів «прагнення досягти життєвої мети» необхідно зазначити, що цей складник визначається суспільними умовами життя і грунтується винятково на потребах, інтересах особистості, іiі ресурсах і можливостях у самореалізації, яка має перспективу стабільності, визначеності у майбутньому. Однак за умов карантину, екстреного переходу від очної до дистанційної форми навчання, в умовах ізольованості та непередбачуваності в особистості може виникати почуття страху за майбутнє, яке руйнує будь-які перспективи, плани, відтак життєва мета стає більш віддаленою в часі. Особливо гостро проявляються такі переживання в особистостей менш гнучких, які поступово пристосовуються до зовнішніх умов життєдіяльності. Відповідно результати дослідження мотиваційного складника майбутніх філологів II зрізу істотно відрізняються від показників I зрізу.

В умовах постійного перебування у віртуальному освітньому просторі, коли вирішення проблем у реальному освітньому середовищі не може стати альтернативою, рівень емоційної стабільності, що відповідає за розуміння власних емоцій, почуттів інших, управління власною емоційною сферою, знижується. Адже не кожен майбутній 
філолог, виконуючи освітні завдання, має безперервний доступ до джерел інформації через відсутність відповідного технічного оснащення, не всі студенти досконало користуються інформаційно-комунікаційними технологіями, не велика кількість здобувачів освіти здатна до самодисципліни, свідомої організації самостійної роботи 3 виконання завдань тощо. Такі недоліки супроводжуються емоційним напруженням, переживаннями, появою негативних почуттів. Крім того, процес становлення майбутнього фахівця спеціальності «Філологія» перш за все передбачає опанування практичними уміннями, навичками володіння мовою, що за умов віртуального освітнього простору обмежене. Це викликає у студентів хвилювання за рівень формування професійної компетентності, тому показник емоційного складника стресостійкості майбутніх філологів II зрізу нижчий за показник стресостійкості студентів I зрізу.

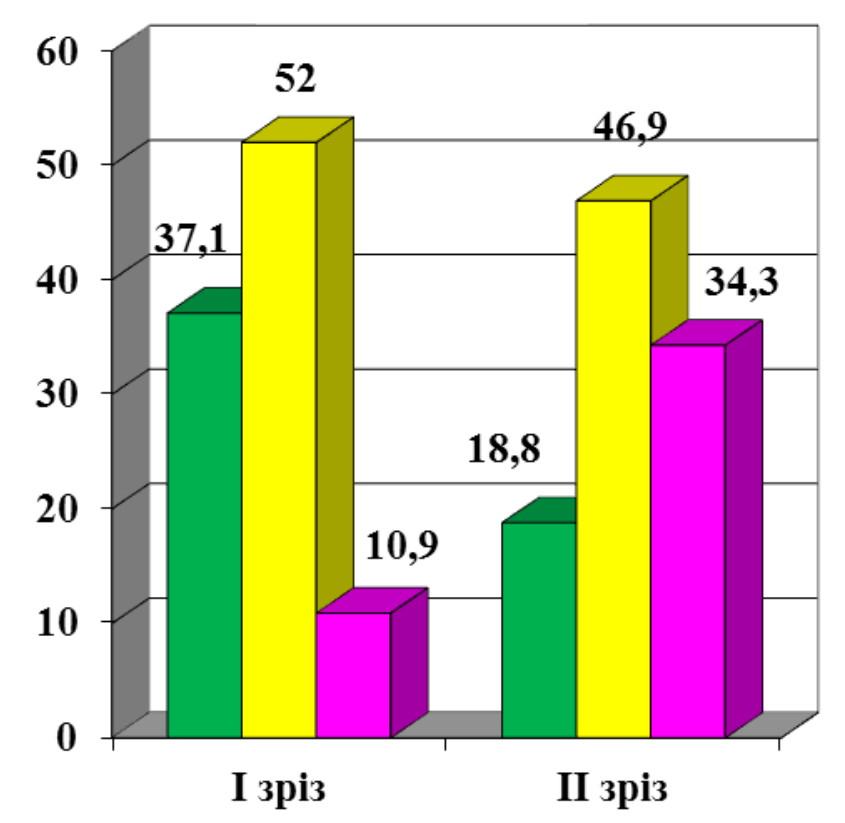

\section{口Високий рівень $\square$ Середній рівень $\square$ Низький рівень}

Рис. 1. Зміни стресостійкості майбутніх філологів відповідно до впливу віртуального освітнього простору за різних умов (у\%).

Важливо зауважити, що причина різниці між показниками діяльнісного складника стресостійкості майбутніх філологів I та II зрізів криється в непередбачуваних умовах існування, які не мали місця в житті студентів ні в штучно створених ситуаціях тренування, ні в реальному відтворенні. Водночас уміння адаптуватися передбачає процес пристосування, розвиток особистості в новому середовищі, що грунтується на розумінні сутності нового простору, умінні коректно реагувати на конкретні ситуації, i може бути сформоване лише під час безпосереднього перебування в змінному середовищі. Швидкість формування вміння адаптуватися залежить від індивідуальнопсихологічних властивостей особистості та попереднього досвіду перебування в новому просторі. Тому очікувати від майбутніх філологів стрімкого гармонійного розвитку вмінь адаптуватися до ненормованого перебування у віртуальному освітньому просторі не уявляється можливим. Крім того, надмірне знаходження у віртуальній реальності позначається як на психічному, так і на фізичному стані студентів, що також вимагає тривалого часу для отримання результату від пристосування до змін. Отже, 
результати дослідження стресостійкості майбутніх філологів показали, що за умов традиційного формату навчання показники стресостійкості студентів вищі, ніж показники стресостійкості здобувачів освіти, які опановують фах у режимі надмірного перебування у віртуальному освітньому просторі.

Варто зауважити, що в умовах сьогодення віртуальний освітній простір $є$ не чимось ефемерним і все частіше стає реальністю, яка створює передумови для трансформації не лише особистісних властивостей майбутніх фахівців, але й підштовхує освітні заклади до пошуку нових рішень. Одним 3 таких варіантів рішень може бути навчання в реально-віртуальному освітньому просторі, що становить інтеграцію реального та віртуального освітніх середовищ, дає змогу кожному учаснику освітнього процесу стати частиною дослідження, спрямованого на організацію відкритого освітнього простору [52], [53]. Головною рисою такого середовища $€$ можливість суб'єктів простору керувати освітніми ситуаціями, оскільки реальновіртуальний освітній простір $\epsilon$ частиною умовної практики, що передбачає конструктивну діяльність, безпосередню участь як викладачів, так і здобувачів освіти. Крім того, такий простір мінливий, вимагає від учасників освітнього процесу застосування багатоманітного досвіду, створення різноманітних освітніх ситуацій. У реально-віртуальному освітньому просторі увага зосереджується на потенційних, ресурсних можливостях учасників, актуалізується роль різноманітних освітніх обставин; усе це змінює не лише мислення, але й діяльність суб'єктів [52, с. 160]. Як зазначає А. Ахаян, за умов реально-віртуального освітнього середовища, використовуючи, наприклад, віртуальну педагогічну студію, студент під час опанування фахового матеріалу самостійно обирає час, місце переходу в підготовлене педагогом віртуальне освітнє середовище (з відеолекціями, аудіозаписами, презентаціями, завданнями для виконання, online i offline каналами комунікації, засобами контролю на основі google-form), у якому можливо підібрати швидкість, послідовність перегляду матеріалу, повторити його фрагменти, встановити обсяг, порядок використання, ознайомитись з інформацією тощо [54]. Важливими в цьому процесі виступають: наявність навчальної мотивації студентів, раціональна організація навчальних, наукових, соціально-гуманітарних заходів, вибір методів, форм, засобів формування фахових компетентностей, комплектація кабінетів відповідним технічним обладнанням, інформаційно-ресурсне забезпечення [53], наявність у педагогів здатності виконувати комп'ютерний дизайн, бути автором текстів, сценаристом, акторомрежисером, відео- і вебмонтажером тощо [54]. За таких умов стресостійкість майбутніх фахівців під час формування фахових компетентностей розвиватиметься рівномірно, поступово, органічно [53].

3 огляду на вищезазначене, спираючись на думку Н. Вербицької, А. Сафронової, рекомендаціями до розвитку стресостійкості майбутніх філологів в умовах реальновіртуального освітнього простору можуть бути такі:

- безперервна взаємодія всіх суб'єктів освітнього процесу, заснована на партнерських відносинах;

- змістове наповнення позанавчальної діяльності студентів науковими, культурно-масовими заходами, конкурсами, конференціями, фокус-групами в реальному середовищі 3 урахуванням особистісного досвіду молоді та комунікацією в соціальних мережах, онлайн квестами, соціальними опитуваннями, форумами, вебінарами, віртуальними виставками тощо;

- систематична модерація віртуального освітнього простору через побудову чіткого алгоритму реалізації освітнього процесу, регулярний моніторинг діяльності студентів у виокремлених мережевих ресурсах, відбір освітніх матеріалів з урахування потреб молоді, безперервний доступ до мережевих 
ресурсів віртуального освітнього простору, усунення труднощів студентів у роботі з мережевими ресурсами;

- інтеграція віртуального досвіду в реальний простір життєдіяльності студентів за допомогою соціалізації у віртуальному просторі через опанування нормами, цінностями, поведінкою в Інтернет-спільнотах, інтеграції в реальні умови життя молоді віртуального виміру [53];

- доступ до сучасних засобів інформаційних технологій, пристроїв, безперебійний доступ до мережі Інтернет у будь-якому місці всіх суб'єктів освітнього процесу задля можливості якісно виконувати функції освітнього характеру;

- формування в усїх суб'єктів освітнього процесу навичок впевненого користування сучасними персональними засобами інформаційних технологій, пристроями, електронними ресурсами тощо;

- наявність менторської підтримки під час виконання освітніх завдань із застосуванням інформаційно-комунікаційних технологій;

- організація освітнього процесу в реально-віртуальному освітньому просторі 3 урахуванням раціонального режиму праці і відпочинку студентів, добових ритмів фізіологічних функцій організму молодої людини;

- застосування особистісно орієнтованого підходу до студентів під час реалізації освітніх завдань із застосуванням інформаційно-комунікаційних технологій;

- формування готовності майбутніх філологів до самопланування, самоорганізації, самоконтролю.

\section{5. ВИСНОВКИ І ПЕРСПЕКТИВИ ПОДАЛЬШИХ ДОСЛІДЖЕНЬ}

Отже, представлене дослідження дало змогу уточнити основні поняття дослідження: «віртуальний освітній простір» визначено як засноване на застосуванні комп'ютерної техніки середовище, яке забезпечує учасників освітнього процесу інформаційними матеріалами за допомогою технологічних інструментів, змістового наповнення; «віртуальний освітній простір Інституту філології Київського університету імені Бориса Грінченка» розглядаємо як відкрите динамічне середовище застосування інформаційно-комунікаційних технологій задля ефективної реалізації освітнього процесу професійної підготовки філологів; «реально-віртуальний освітній простір» характеризуємо як інтеграцію реального та віртуального освітніх середовищ, які дають змогу кожному учаснику освітнього процесу стати частиною дослідження, спрямованого на організацію відкритого освітнього простору; «стресостійкість» розуміємо як здатність людини долати вплив значущих стрес-факторів задля мінімізації шкідливих наслідків для організму.

Зважаючи на особливості формування фахових компетентностей майбутніх філологів (здатності використовувати знання про мову як знакову систему; здатності застосовувати мову в усній і письмовій формі, збирати, інтерпретувати літературні факти, створювати, здійснювати аналіз текстів різних жанрів, стилів; спроможності здійснювати консультації з дотримання норм мови та культури мовлення, здатності до ділової комунікації тощо), основи їх життєдіяльності, у жовтні 2019 року в умовах традиційного формату освітнього середовища було проведено дослідження рівня стресостійкості студентів-філологів. Результати опитування майбутніх фахівців Інституту філології Київського університету імені Бориса Грінченка свідчать про достатньо розвинену стресостійкість студентів і про створені сприятливі умови для підтримання досліджуваного явища на належному рівні у процесі формування фахових 
компетентностей. Емпірично було доведено, що традиційний (очний) формат освітнього середовища, який містить і елементи віртуального освітнього простору, ефективно впливає на врівноваженість студентів під час професійної підготовки. За таких умов майбутні філологи мають позитивні наміри досягти життєвих цілей, готові до будь-яких змін, впевнено вирішують завдання професійного характеру, легко адаптуються до різних обставин життя, поступово опановуючи сучасні інформаційнокомунікаційні технології.

Здійснене дослідження у червні 2020 року в умовах карантину і надмірного перебування майбутніх філологів у віртуальному освітньому просторі через самостійне опанування аспектів використання сучасних технічних засобів трансляції інформації та виконання технічно-організаційної роботи із завантаження, оброблення, пересилання матеріалів показало, що рівень стресостійкості студентів значно знизився.

Особливості впливу віртуального освітнього простору на стресостійкість майбутніх філологів за різних умов, а саме: періодичне користування студентів елементами віртуального освітнього простору сприятливо впливає на розвиток стресостійкості майбутніх фахівців, формування їх фахових компетентностей; надмірне перебування у віртуальному освітньому просторі студентів знижує рівень їх стресостійкості, - активізують необхідність усвідомлення особливостей розвитку стресостійкості майбутніх філологів, зокрема становлення особистості загалом; виокремлення аспектів освітнього простору як традиційного, так і дистанційного формату, які потребують трансформації; внесення коректив в умови навчання майбутніх філологів; визначення альтернативного способу розв'язання проблеми на користь реально-віртуального освітнього простору. Визначено рекомендації з розвитку стресостійкості майбутніх філологів в умовах реально-віртуального освітнього простору, а саме: наявність партнерських взаємин між суб'єктами освітнього процесу; різноманітність позанавчальної діяльності студентів; безперервна організаційна, менторська підтримка реалізації освітнього процесу; врахування валеологічних аспектів в організації освітнього процесу; наявність сучасних засобів інформаційних технологій, уміння всіх суб'єктів освітнього процесу користуватися ними; особистісноорієнтований підхід до студентів, розвиток у них навичок самопланування, самоорганізації, самоконтролю; соціалізація молоді у віртуальному просторі.

У подальших дослідженнях важливо розглянути теоретико-методологічні основи проблеми реально-віртуального освітнього простору і концептуальних підходів до його створення в сучасних освітніх умовах.

\section{ПОДЯКА}

Автори висловлюють подяку респондентам опитування за допомогу в дослідженні стресостійкості в умовах карантину, зокрема студентам спеціальності 035 «Філологія» Інституту філології Київського університету імені Бориса Грінченка.

\section{СПИСОК ВИКОРИСТАНИХ ДЖЕРЕЛ}

[1] H. Bland, B. Melton, P. Welle, and L. Bigham, «Stress Tolerance: New Challenges for the Millennial College Students», College Student Journal, no 46(2), pp. 362-375, 2012. [Електронний ресурс]. Доступно: https://digitalcommons.georgiasouthern.edu/commhealth-facpubs/32/. Дата звернення: Серпень 10, 2020.

[2] T. Hicks, and S. Heastie, «High school to college transition: A profile of the Stressors, physical and psychological health issues that affect the first-year on-campus college student», Journal of Cultural Diversity, no 15(3), pp. 143-147, 2008. [Електронний ресурс]. Доступно: 
https://pdfs.semanticscholar.org/06bf/56085502095a0c7096e10b87e3f1cbae8a7a.pdf. Дата звернення: Серпень 10, 2020.

[3] В.І. Коновальчук, Творча особистість у просторі освіти. Умань: ФОП Жовтий О.О., 2016.

[4] А. Шевцов, О. Ласточкіна, та Н. Николенко, «Підготовка вчителів спеціальної освіти в Україні та за кордоном в умовах екстренного запровадження дистанційного навчання», Інформаційні технології $і$ засоби навчання, Т. 77, № 3, с. 240-261, 2020. [Електронний ресурс]. Доступно: https://journal.iitta.gov.ua/index.php/itlt/article/view/3960. Дата звернення: Серпень 10, 2020.

[5] J. Zounek, and P. Sudický, «Heads in the Cloud: Pros and Cons of Online Learning», in New technologies and media literacy education International conference DisCo, 2013, Prague, pp. 58-63. [Електронний pecypc]. Доступно: https://www.researchgate.net/publication/311807840_Heads_in_the_ Cloud_Pros_and_Cons_of_Online Learning. Дата звернення: Серпень 10, 2020.

[6] L. Darling-Hammond, Lisa. Flook, C. Cook-Harvey, B. Barron, and D. Osher, «Implications for educational practice of the science of learning and development», Applied Developmental Science, no 24 (2), pp. 97-140, 2020. doi: 10.1080/10888691.2018.1537791.

[7] Н. Рибка, «Є диний освітній простір як інтегративна система: соціально-філософський аналіз», автореф. дис. канд. філос. наук., Одеса, 2005, 24 с. [Електронний ресурс]. Доступно: http://referatu.net.ua/referats/7569/161733. Дата звернення: Серпень 10, 2020.

[8] Т. Ткач, Освітній простір особистості: психологічний аспект. Київ, 2008. 272 c.

[9] А. Цимбалару, «Освітній простір: сутність, структура і механізми створення», Украӥнський педагогічний журнал, № 1, с. 41-50, 2016. [Електронний ресурс]. Доступно: https://scholar.google.com.ua/citations?user=8EPKzDcAAAAJ\&hl=uk. Дата звернення: Серпень 10, 2020.

[10] В. Биков, О. Буров, А. Гуржій, М. Жалдак, М. Лещенко, С. Литвинова, В. Луговий, В. Олійник, О. Спірін, та М. Шишкіна, Розвиток теоретичних основ інформатизаиії освіти та практична реалізаиія інформаиійно-комунікаиійних технологій в освітній сфері Украӥни. Житомир: ЖДУ ім. I. Франка, 2019. [Електронний ресурс]. Доступно: https://iitlt.gov.ua/info/news/proekti/rozvytokteoretychnykh-osnov-informatyzatsiyi-osvity-ta-praktychna-realizatsiya-informatsiyno-komuni/. Дата звернення: Серпень 10, 2020.

[11] Н. Морзе, та Л. Варченко-Троценко, «Використання wiki-технології для організації навчального середовища сучасного університету», in International scientific conference. Open educational eenvironment of modern University, 2015, Kyiv, pp. 115-125. doi: https://doi.org/10.28925/24140325.2015.1.115n25.

[12] А. Нашинець-Наумова, В. Бурячок, Н. Коршун, О. Жильцов, та П. Складанний, «Технологія забезпечення інформаційної і кібербезпеки в закладах вищої освіти україни», Інформаційні технології і засоби навчання, Т. 77, № 3, с. 337-354, 2020. [Електронний ресурс]. Доступно: https://journal.iitta.gov.ua/index.php /ittl/article/view/3424. Дата звернення: Серпень 10, 2020.

[13] K. Ratheeswari, «Information Communication Technology in Education», Journal of Applied and Advanced Research, № 3(1), pp. 45-47, 2018. doi: 10.21839/jaar.2018.v3iS1.169.

[14] Г. Швачич, В. Толстой, Л. Петречук， Ю. Іващенко, О. Гуляєва, та О. Соболенко, Сучасні інформаиійно-комунікаиійні технології. Дніпро, 2017. 230 с.

[15] Є. М. Карпенко, та М. Айтай-Хорвас, «Цифрове оповідання як засіб активізації пізнавальної діяльності молодших школярів на уроці іноземної мови», Інформаиійні технології $i$ засоби навчання, 81(1), 36-45, 2021. https://doi.org/10.33407/itlt.v81i1.3149/

[16] О. В. Асадчих, та Т. С. Перелома, «Поліфункціональне використання цифрових додатків у процесі навчання майбутніх філологів-орієнталістів», Інформаиійні технологї $i$ засоби навчання, 81(1), 154-166, 2021. https://doi.org/10.33407/itlt.v81i1.3299

[17] Е. О. Помиткін, Л. В. Помиткіна, та О. В. Іванова, «Дослідження емоційних станів учителів нуш у період пандемії covid-19 з використанням електронного ресурсу». Інформащійин технології $i$ засоби навчання, 80(6), 267-280, 2020. https://doi.org/10.33407/itlt.v80i6.4179.

[18] О. А. Кучерук, С. О. Караман, та О. В. Караман, «Науково-освітні електронні бібліотеки у фаховій підготовці майбутніх учителів-словесників», Інформаційні технології $і$ засоби навчання, Т. 65, № 3, c. 152-165, 2018. [Електронний ресурс]. Доступно: http://journal.iitta.gov.ua/index.php/itlt. Дата звернення: Липень 17, 2021.

[19] О.А. Кучерук， С.О. Караман， О.В. Караман， та Н.М. Віннікова， «Використання ІКТ для формування фахових компетентностей у майбутніх учителів української мови і літератури», Інформаційні технології і засоби навчання, Т. 71, № 3, с. 196-214, 2019. [Електронний ресурс]. Доступно: https://journal.iitta.gov.ua/index.php/itlt/article/view/2814/1496. Дата звернення: Липень 17, 2021.

[20] Л Лук'янова, Г. Товканець, Г. Сотська, та О. Тринус, «Соціально-педагогічні аспекти діяльності віртуальних університетів у Європейському освітньому просторі», Інформаиійні технології $i$ 
засоби навчання, Т. 72, № 4, с. 14-25, 2019. [Електронний ресурс]. Доступно: https://journal.iitta.gov.ua/index.php/itlt/article/view/2892/1540. Дата звернення: Березень 31, 2021.

[21] I. Chamine, B. Oken, and W. Wakeland, «A systems approach to stress, stressors and resilience in humans», Behavioural Brain Research, № 282, pp. 144-154, 2015. doi:10.1016/j.bbr.2014.12.047.

[22] G. Essel, and P. Owusu, Causes of Students» Stress, its effects on their stress management by students. A case study at Seinajoki, Finland, 2017. [Електронний ресурс]. Доступно: https://pdfs.semanticscholar.org/ec11/dcd79b0eed18efaf87a50b097ec6b7bf2327.pdf?_ga=2.153315384. 1869977557.1597229111-126544180. 1597229111. Дата звернення: Серпень 10, 2020.

[23] S. Hobfoll, The Ecology of Stress. Washington: Hemisphere, 1988. [Електронний ресурс]. Доступно: http://psycnet.apa.org/record/1988-98279-000. Дата звернення: Серпень 10, 2020.

[24] Н. Лебідь, Стресостійкість як особистісна властивість керівників-лідерів закладів середньої освіти. Київ, 2016. [Електронний ресурс]. Доступно: https://docplayer.net/71669541-Stresostiykistyak-osobistisna-vlastivist-kerivnikiv-lideriv-zakladiv-serednoyi-osviti.html. Дата звернення: Серпень $10,2020$.

[25] О. Вознюк, «Кіберсоціалізаційні наслідки комп’ютеризації як суттєвого чинника побудови сучасного інформаційного простору», Наукові записки Малої академії наук України, Вип. 4, с. 2335, 2013. [Електронний pecypc]. Доступно: http://eprints.zu.edu.ua/22860/1/\%D0 $\% 92 \%$ D0\%BE\%D0\%B7\%D0\%BD\%D1\%8E\%D0\%BA_\%D0\%9C\%D0\%90\%D0\%9D_\%D1\%81\%D1\% 82\%D0\%B0\%D1\%82\%D1\%82\%D1\%8F_3_\%D0\%B1\%D0\%B5\%D0\%B7_\%D0\%BD\%D0\%BE\%D0\% BC\%D0\%B5\%D1\%80\%D0\%BE\%D0\%B2.PDF. Дата звернення: Серпень 10, 2020.

[26] M. Carroll-Mayer, B. Marcinkowski, and M. Płotka, «Non-attendance factors - can e-learning be considered a disincentive?» Information Technologies and Learning Tools, V. 76, № 2, pp. 177-186, 2020. [Електронний ресурс]. Доступно: https://journal.iitta.gov.ua/index.php/itlt/article/view/3404. Дата звернення: Серпень 10, 2020.

[27] С. Семчук, «Медіасоціалізуючий вплив комп’ютерних технологій на молоде покоління», Збірник наукових праць Уманського державного педагогічного університету імені Павла Тичини, Ч. 3, c. 321-329, 2014. [Електронний ресурс]. Доступно: http://nbuv.gov.ua/UJRN/znpudpu_2014_3_45. Дата звернення: Серпень 10, 2020.

[28] N. Elmqaddem, «Augmented Reality and Virtual Reality in Education. Myth or Reality?», International journal of emerging technologies in learning, V. 14, No 3, pp. 234-242, 2019. doi: 10.3991/ijet.v14i03.9289

[29] Ю. Трач, «Віртуалізація освіти як явище сучасної культури», Культура і мистецтво у сучасному cвimi, Вип. 19, с. 164-172, 2018. [Електронний ресурс]. Доступно: http://nbuv.gov.ua/UJRN/Kmss_ 2018_19_19. Дата звернення: Серпень 10, 2020.

[30] В. Климнюк, «Віртуальна реальність в освітньому процесі», Збірник наукових праць Харківського національного університету Повітряних Сил, № 2(56), с. 207-212, 2018. [Електронний ресурс]. Доступно: http://nbuv.gov.ua/UJRN/ZKhUPS_2018_2_30. Дата звернення: Серпень 10, 2020.

[31] М. Смульсон, «Психологічна характеристика віртуального освітнього простору», Наука $i$ освіта, № 10, с. 10-15, 2015. [Електронний ресурс]. Доступно: http://nbuv.gov.ua/UJRN/NiO_2015_10_4. Дата звернення: Серпень 10, 2020.

[32] T. Oppenheimer, The Flickering Mind: Saving Education from the False Promise of Technology. N.Y.: Random House, Trade Paperback, 2003. [Електронний pecypc]. Доступно: https://www.semanticscholar.org/paper/The-Flickering-Mind\%3A-Saving-Education-from-the-ofOppenheimer/3892535d8234624bdcafcb4fc9f18ece40f02b55. Дата звернення: Серпень 10, 2020.

[33] Інституційний репозиторій Київського університету імені Бориса Грінченка. [Електронний peсурс]. Доступно: http://elibrary.kubg.edu.ua/. Дата звернення: Серпень 05, 2021.

[34] Київський університет імені Бориса Грінченка. [Електронний ресурс]. Доступно: https://kubg.edu.ua. Дата звернення: Серпень 05, 2021.

[35] Facebook. Кафедра української літератури, компаративістики і грінченкознавства. [Електронний pecypc]. Доступно: https://www.facebook.com/kulk.if. Дата звернення: Серпень 05, 2021.

[36] Facebook. Translation Centre at Grinchenko University. [Електронний ресурс]. Доступно: https://www.facebook.com/pg/Translation-Centre-at-Grinchenko-University-11174217 6206968/posts/. Дата звернення: Серпень 05, 2021.

[37] Facebook. Центр культури української мови. [Електронний ресурс]. Доступно: https://www.facebook.com/groups/2061838847428315. Дата звернення: Серпень 05, 2021.

[38] Facebook. Кафедра романської філології та порівняльно-типологічного мовознавства. [Електронний ресурс]. Доступно: https://www.facebook.com/romanceKubg. Дата звернення: Серпень 05, 2021.

[39] Facebook. По-літ. [Електронний ресурс]. Доступно: https://www.facebook.com/politkubg. Дата звернення: Серпень 05, 2021. 
[40] Facebook. Кафедра східних мов i перекладу. [Електронний ресурс]. Доступно: https://www.facebook.com/ks.kubg/. Дата звернення: Серпень 05, 2021.

[41] Facebook. Кафедра германської філології. [Електронний ресурc]. Доступно: https://www. facebook.com/profile.php?id=100024688208725. Дата звернення: Серпень 05, 2021.

[42] Youtube. Центр компетентностей «Літературний театр». [Електронний ресурс]. Доступно: https://www.youtube.com/channel/UCnzEaJoE-jicZ8DqXi-yuzA. Дата звернення: Серпень 05, 2021.

[43] Youtube. Інститут філології. [Електронний ресурс]. Доступно: https://www.youtube.com/channel/UCyt0Ay3pPXF23B5eeGtf9QA. Дата звернення: Серпень 05, 2021.

[44] Youtube. Кафедра світової літератури. [Електронний ресурс]. Доступно: https://www.youtube.com/channel/UCMW9QYYYy606xmPTZQQNAHw. Дата звернення: Серпень 05, 2021.

[45] Youtube. Студентська рада Інституту філології. [Електронний ресурс]. Доступно: https://m.youtube.com/channel/UCnLiG3med TYQ-L2d5Fn52gA. Дата звернення: Серпень 05, 2021.

[46] Центр культури української мови. [Електронний ресурс]. Доступно: http://centrkum.blogspot.com/p/blog-page_17.html. Дата звернення: Серпень 05, 2021.

[47] Telegram. Центр перекладу. [Електронний ресурс]. Доступно: https://xn--80affa3aj0al.xn-80asehdb/\#/im?p=@transl_kubg. Дата звернення: Серпень 05, 2021.

[48] Telegram. Центр культури української мови. [Електронний ресурс]. Доступно: https://xn-80affa3aj0al.xn--80asehdb/\#/im?p=@kulturaukrmovi. Дата звернення: Серпень 05, 2021.

[49] Telegram. Студентська рада Інституту філології. [Електронний ресурс]. Доступно: https://xn-80affa3aj0al.xn--80asehdb/\#/im?p=@ students_if. Дата звернення: Серпень 05, 2021.

[50] Instagram. Інститут філології. [Електронний ресурс]. Доступно: https://instagram.com/if.kubg. edu.ua?igshid=1rnnp4rbe6txјна. Дата звернення: Серпень 05, 2021.

[51] Instagram. Кафедра східних мов і перекладу. [Електронний ресурс]. Доступно: https://www.instagram.com/ksmp_kubg/?igshid=lyvs34qjkm2e. Дата звернення: Серпень 05, 2021.

[52] И. Королюк, «Влияние реально-виртуального образовательного пространства на деятельность педагога», Гуманитарные, соииально-экономические и общественные науки, № 11-12, с. 158-163, 2015. [Електронний ресурс]. Доступно: https://cyberleninka.ru/article/n/vliyanie-realno-virtualnogoobrazovatelnogo-prostranstva-na-deyatelnost-pedagoga. Дата звернення: Серпень 10, 2020.

[53] А. Сафронова, и Н. Вербицкая, «Реально-виртуальная воспитательная среда вуза как педагогическое средство формирования у студентов навыков самосохранения здоровья», Научное обозрение. Педагогические науки, № 2, с. 32-37, 2018. [Електронний ресурс]. Доступно: https://science-pedagogy.ru/ru/article/view?id=1749. Дата звернення: Серпень 10, 2020.

[54] А. А. Ахаян, «Трехмерное виртуальное образовательное пространство как образовательное пространство сетевой личности», Сочиальная работа: современные проблемы и технологий, № 1 , c. 12-17, 2020. [Електронний ресурc]. Доступно: https://elibrary.ru/item.asp?id=42358138. Дата звернення: Липень 23, 2021.

Матеріал надійшов до редакиії 05.11.2020 p.

\title{
ВЛИЯНИЕ ВИРТУАЛЬНОГО ОБРАЗОВАТЕЛЬНОГО ПРОСТРАНСТВА НА СТРЕССОУСТОЙЧИВОСТЬ БУДУЩИХ ФИЛОЛОГОВ
}

\author{
Руснак Ирина Евгеньевна \\ доктор филологических наук, профессор, директор Института филологии \\ Киевский университет имени Бориса Гринченко, г. Киев, Украина \\ ORCID ID 0000-0001-8355-7389 \\ i.rusnak@kubg.edu.ua
}

\section{Саврасова-Выюн Татьяна Александровна}

кандидат психологических наук, заместитель директора Института филологии по научно-педагогической и социально-гуманитарной работе

Киевского университета имени Бориса Гринченко, г. Киев, Украина

ORCID ID 0000-0001-5737-6189

t.savrasova-viun@kubg.edu.ua

\section{Заяц Людмила Ивановна}

кандидат педагогических наук,

заместитель директора Института филологии по научно-методической и учебной работе

Киевский университет имени Бориса Гринченко, г. Киев, Украина 
ORCID ID 0000-0003-1751-1301

l.zaiats@kubg.edu.ua

Доценко Елена Леонидовна

кандидат филологических наук, доцент,

заместитель директора Института филологии по научной работе и международным проектам

Киевский университет имени Бориса Гринченко, г. Киев, Украина

ORCID ID 0000-0003-4607-0883

o.dotsenko@kubg.edu.ua

\begin{abstract}
Аннотация. В статье освещена актуальная проблема влияния современного виртуального образовательного пространства на стрессоустойчивость будущих филологов классического университета. Отмечено, что в условиях безотлагательного внедрения в систему образования карантинного режима и перехода на дистанционную форму обучения, освоение виртуального образовательного пространства стало первоочередной задачей не только для профессорско-преподавательского состава высшего учебного заведения, но и будущих специалистов. Описан опыт организации виртуальной образовательной среды с применением средств дистанционного обучения на базе Института филологии Киевского университета имени Бориса Гринченко и их влияние на стрессоустойчивость будущих филологов. Отмечено, что благодаря виртуальному образовательному пространству Института будущие филологи овладевают навыками практического применения языка в профессиональном, ситуативном общении, формируют новый подход к методике обучения языку и литературе, могут интегрировать средства ИКТ в будущей профессиональной деятельности. Определено содержание, структура стрессоустойчивости будущих специалистов, подобран методический инструментарий исследования уровня стрессоустойчивости студентов. Актуальность темы подтверждена приведенными результатами опроса будущих филологов, которые проходили диагностику по проблеме изучения уровня стрессоустойчивости как в условиях традиционной формы обучения, так и в режиме дистанционного обучения. В эксперименте приняли участие 214 студентов специальности 035 «Филология». Путем экспериментальной деятельности выделены особенности влияния виртуального образовательного пространства на стрессоустойчивость будущих филологов. Выявлено, что уровень стрессоустойчивости будущих филологов в условиях традиционного обучения выше, чем уровень стрессоустойчивости студентов в условиях чрезмерного пребывания в виртуальном образовательном пространстве. Предложено альтернативное решение: реально-виртуальное образовательное пространство как изменчивая среда, в которой субъекты пространства могут управлять образовательными ситуаціями. Указаны рекомендации по развитию стрессоустойчивости будущих филологов в условиях реально-виртуального образовательного пространства.
\end{abstract}

Ключевые слова: виртуальное образовательное пространство; дистанционная форма обучения; онлайн-обучения; информационно-коммуникационные технологии; реальновиртуальное образовательное пространство; стрессоустойчивость будущих филологов.

\title{
THE INFLUENCE OF THE VIRTUAL EDUCATIONAL SPACE ON THE FUTURE PHILOLOGISTS' STRESS RESISTANCE
}

\section{Iryna E. Rusnak}

Doctor of Sciences in Philology, Professor, Director of the Institute of Philology

Borys Grinchenko Kyiv University, Kyiv, Ukraine

ORCID ID 0000-0001-8355-7389

i.rusnak@kubg.edu.ua

Tetiana O. Savrasova-V'un

$\mathrm{PhD}$ in Psychology, Deputy Director of the Institute of Philology

Borys Grinchenko Kyiv University, Kyiv, Ukraine

ORCID ID 0000-0001-5737-6189

t.savrasova-viun@kubg.edu.ua

Liudmyla I. Zaiats

$\mathrm{PhD}$ of Pedagogical Sciences, Deputy Director of the Institute of Philology 
Borys Grinchenko Kyiv University, Kyiv, Ukraine

ORCID ID 0000-0003-1751-1301

l.zaiats@kubg.edu.ua

\title{
Olena L. Dotsenko
}

PhD in Philology, Associate Professor, Deputy Director of the Institute of Philology

Borys Grinchenko Kyiv University, Kyiv, Ukraine

ORCID ID 0000-0003-4607-0883

o.dotsenko@kubg.edu.ua

\begin{abstract}
The article highlights the actual problem concerning the influence of the modern virtual educational space on the future philologists' stress resistance at a classical university. It is noted that in the conditions of urgent introduction of quarantine mode into the educational system and the transition to distance learning, development of virtual educational space has become a priority task not only for the teaching staff of a higher educational institution, but also for future specialists. The experience of organizing a virtual educational environment by using distance learning tools on the basis of the Institute of Philology of Borys Grinchenko Kyiv University and their impact on the future philologists' stress resistance is described. It is noted that thanks to the virtual educational space of the Institute, future philologists master practical language application skills in professional, situational communication, form a new approach to language and literature teaching methodology, can integrate ICT tools in future professional activities. The content and structure of stress resistance of future specialists is defined, the methodological tools of research into the level of students' stress resistance are selected. The relevance of the topic is confirmed by the given results of the survey of the future philologists who underwent diagnostics on the problem of studying the level of stress resistance both in the conditions of the traditional form of education and in the distance learning mode. 214 students of the specialty 035 «Philology» took part in the experiment. By means of experimental activities, the features of the influence of the virtual educational space on the future philologists' stress resistance have been identified. It was revealed that the level of future philologists' stress resistance in the conditions of traditional education is higher than the level of students' stress resistance in excessive stay in the virtual educational space. An alternative solution is proposed: a real-virtual educational space as a changeable environment in which the individuals can control educational situations. Recommendations for the development of stress resistance of future philologists in the conditions of a real-virtual educational space are indicated.
\end{abstract}

Keywords: virtual educational space; distance learning; online learning; information and communication technologies; real-virtual educational space; stress resistance of future philologists.

\section{REFERENCES (TRANSLATED AND TRANSLITERATED)}

[1] H. Bland, et al., «Stress Tolerance: New Challenges for the Millennial College Students», College Student Journal, Iss. 46(2), pp. 362-375, 2012. [Online]. Available: https://digitalcommons.georgiasouthern.edu/commhealth-facpubs/32/. Accessed on: August 10, 2020 (in English).

[2] T. Hicks, et al., «High school to college transition: A profile of the Stressors, physical and psychological health issues that affect the first-year on-campus college student», Journal of Cultural Diversity, Iss. 15(3), pp. 143-147, $2008 . \quad$ [Online]. Available: https://pdfs.semanticscholar.org/06bf/56085502095a0c7096e10b87e3f1cbae8a7a.pdf. Accessed on: August 10, 2020 (in English).

[3] V. I. Konoval chuk, «Creative personality in the space of education». Uman, 2016 (in Ukrainian).

[4] A. Shevczov, et al., «Training of special education teachers in Ukraine and abroad in the conditions of emergency introduction of distance learning», Information Technologies and Learning Tools, Iss. 77, no. 3, pp. 240-261, 2020. [Online]. Available: https://journal.iitta.gov.ua/index.php/itlt/article/view/3960. Accessed on: August 10, 2020 (in Ukrainian).

[5] J. Zounek, et al., «Heads in the Cloud: Pros and Cons of Online Learning», New technologies and media literacy education International conference DisCo, 2013, Prague, pp. 58-63. [Online]. Available: https://www.researchgate.net/publication/311807840_Heads_in_the_Cloud_Pros_and_Cons_of_Online_ Learning. Accessed on: August 10, 2020 (in English). 
[6] L. Darling-Hammond, et al., «Implications for educational practice of the science of learning and development», Applied Developmental Science, Iss. 24(2), pp. 97-140, 2020. doi: https://doi: 10.1080/10888691.2018.1537791. Accessed on: August 10, 2020 (in English).

[7] N. Ry`bka, «Unified educational space as an integrative system: socio-philosophical analysis». Odesa, 2005. [Online]. Available: http://referatu.net.ua/referats/7569/161733. Accessed on: August 10, 2020 (in Ukrainian).

[8] T. Tkach, «Educational space of personality: psychological aspect». Kyiv, 2008 (in Ukrainian).

[9] A. Cy`mbalaru, «Educational space: essence, structure and mechanisms of creation», Ukrainian pedagogical journal, no. 1, pp. 41-50, 2016. [Online]. Available: https://scholar.google.com.ua/citations?user=8EPKzDcAAAAJ\&hl=uk. Accessed on: August 10, 2020 (in Ukrainian).

[10] V. By'kov, et al., «Development of theoretical foundations of informatization of education and practical implementation of information and communication technologies in the educational sphere of Ukraine». Zhytomyr, 2019. [Online]. Available: https://iitlt.gov.ua/info/news/proekti/rozvytok-teoretychnykhosnov-informatyzatsiyi-osvity-ta-praktychna-realizatsiya-informatsiyno-komuni/. Accessed on: August 10, 2020 (in Ukrainian).

[11] N. Morze, et al., «Using wiki-technology to organize the learning environment of a modern university», International scientific conference. Open educational eenvironment of modern University, 2015, Kyiv, pp. 115-125.doi: https://doi.org/10.28925/2414-0325.2015.1.115n25. Accessed on: August 10, 2020 (in Ukrainian).

[12] A. Nashy`necz'-Naumova, et al., «Technology of information and cybersecurity in higher education institutions of Ukraine», Information Technologies and Learning Tools, Iss. 77, no. 3, pp. 337-354, 2020. [Online]. Available: https://journal.iitta.gov.ua/index.php /itlt/article/view/3424. Accessed on: August 10, 2020 (in Ukrainian).

[13] K. Ratheeswari, «Information Communication Technology in Education», Journal of Applied and Advanced Research, no. 3(1), pp. 45-47, 2018.doi: 10.21839/jaar.2018.v3iS1.169. Accessed on: August 10, 2020 (in English).

[14] G. Shvachy`ch, et al., Modern information and communication technologies. Dnipro, 2017 (in Ukrainian).

[15] I. M. Karpenko, et al, «Digital storytelling as a means of activating the cognitive activity of junior schoolchildren in a foreign language lesson». Information Technologies and Learning Tools, 81(1), pp. 36-45, 2021.doi: https://doi.org/10.33407/itlt.v81i1.3149. Accessed on: August 10, 2020 (in Ukrainian).

[16] O. V. Asadchykh, et al, «Multifunctional use of digital applications in the training of future oriental philologists». Information Technologies and Learning Tools, 81(1), pp.154-166, 2021.doi: https://doi.org/10.33407/itlt.v81i1.3299. Accessed on: August 10, 2020 (in Ukrainian).

[17] E. O. Pomytkin, et al, «Study of emotional states of nush teachers during the covid-19 pandemic using an electronic resource». Information Technologies and Learning Tools, 80(6), pp. 267-280, 2020.doi: https://doi.org/10.33407/itlt.v80i6.4179. Accessed on: August 10, 2020 (in Ukrainian).

[18] O. A. Kucheruk, et al, «Scientific and educational electronic libraries in the professional training of future teachers of vocabulary». Information Technologies and Learning Tools, T. 65, no. 3, pp. 152-165, 2018. [Online]. Available: http://journal.iitta.gov.ua/index.php/itlt. Accessed on: July 17, 2021 (in Ukrainian).

[19] O. A. Kucheruk, et al, «The use of ICT for the formation of professional competencies in future teachers of Ukrainian language and literature», Information Technologies and Learning Tools, T. 71, no. 3, pp. 196-214, 2019. [Online]. Available: https://journal.iitta.gov.ua/index.php/itlt/article/view/2814/1496. Accessed on: July 17, 2021 (in Ukrainian).

[20] L. Lukianova, et al, «Socio-pedagogical aspects of virtual universities in the European educational space», Information Technologies and Learning Tools, T. 72, no. 4, pp. 14-25, 2019. [Online]. Available: https://journal.iitta.gov.ua/index.php/itlt/article/view/2892/1540. Accessed on: August 10, 2020 (in Ukrainian).

[21] I. Chamine, et al., «A systems approach to stress, stressors and resilience in humans», Behavioural Brain Research, no. 282, pp. 44-154, 2015.doi: https://doi:10.1016/j.bbr.2014.12.047. Accessed on: August 10, 2020 (in English).

[22] G. Essel, et al., «Causes of Students» Stress, its effects on their stress management by students. A case study at Seinajoki», $\quad$ Finland, $2017 . \quad$ [Online]. https://pdfs.semanticscholar.org/ec11/dcd79b0eed18efaf87a50b097ec6b7bf2327.pdf?_ga=2.153315384. 1869977557.1597229111-126544180. 1597229111 Accessed on: August 10, 2020 (in English).

[23] S. Hobfoll, «The Ecology of Stress». Washington: Hemisphere, 1988. [Online]. Available: http://psycnet.apa.org/record/1988-98279-000. Accessed on: August 10, 2020 (in English). 
[24] N. Lebid, «Stress resistance as a personal property of leaders-leaders of secondary education institutions. Kyiv, 2016. [Online]. Available: https://docplayer.net/71669541-Stresostiykist-yakosobistisna-vlastivist-kerivnikiv-lideriv-zakladiv-serednoyi-osviti.html. Accessed on: August 10, 2020 (in Ukrainian).

[25] O. Voznyuk, «Cybersocialization consequences of computerization as an essential factor in building a modern information space», Scientific Notes of the Small Academy of Sciences of Ukraine, Iss. 4, pp. 2335, 2013. [Online]. Available: http://eprints.zu.edu.ua/22860/1/\%D0 \%92\%D0\%BE\%D0\%B7\%D0\%BD\%D1\%8E\%D0\%BA_\%D0\%9C\%D0\%90\%D0\%9D_\%D1\%81\%D1\% $82 \% \mathrm{D} 0 \% \mathrm{~B} 0 \% \mathrm{D} 1 \% 82 \% \mathrm{D} 1 \% 82 \% \mathrm{D} 1 \% 8 \mathrm{~F} \_3 \_\% \mathrm{D} 0 \% \mathrm{~B} 1 \% \mathrm{D} 0 \% \mathrm{~B} 5 \% \mathrm{D} 0 \% \mathrm{~B} 7$ \%D0\%BD\%D0\%BE\%D0\% $\mathrm{BC} \% \mathrm{D} 0 \% \mathrm{~B} 5 \% \mathrm{D} 1 \% 80 \% \mathrm{D} 0 \% \mathrm{BE} \% \mathrm{D} 0 \% \mathrm{~B} 2 . \mathrm{PDF}$ Accessed on: August 10, 2020 (in Ukrainian).

[26] M. Carroll-Mayer, et al., «Non-attendance factors - can e-learning be considered a disincentive?» Information Technologies and Learning Tools, Iss. 76, no. 2, pp. 177-186, 2020. [Online]. Available: https://journal.iitta.gov.ua/index. php/itlt/article/view/3404, Accessed on: August 10, 2020 (in English).

[27] S. Semchuk, «Media-socializing influence of computer technologies on the younger generation», Collection of scientific works of Uman State Pedagogical University named after Pavel Tychyna, Iss. 3, pp. 321-329, 2014. [Online]. Available: http://nbuv.gov.ua/UJRN /znpudpu_2014_3_45. Accessed on: August 10, 2020 (in Ukrainian).

[28] N. Elmqaddem, «Augmented Reality and Virtual Reality in Education. Myth or Reality?», International journal of emerging technologies in learning, Iss. 14, № 3, pp. 234-242, 2019.doi: https://doi: 10.3991/ijet.v14i03.9289. Accessed on: August 10, 2020 (in English).

[29] Yu. Trach, «Virtualization of education as a phenomenon of modern culture», Culture and art in the modern world, Iss. 19, pp. 164-172, 2018. [Online]. Available: http://nbuv.gov.ua/UJRN/Kmss_ 2018_19_19. Accessed on: August 10, 2020 (in Ukrainian).

[30] V. Kly`mnyuk, «Virtual reality in the educational process», Collection of scientific works of Kharkiv National University of the Air Force, no. 2(56), pp. 207-212, 2018. [Online]. Available: http://nbuv.gov.ua/UJRN/ZKhUPS_2018_2_30. Accessed on: August 10, 2020 (in Ukrainian).

[31] M. Smul`son, «Psychological characteristics of the virtual educational space», Science and Education, no. 10, pp. 10-15, 2015. [Online]. Available: http://nbuv.gov.ua/UJRN/NiO_2015_10_4. Accessed on: August 10, 2020 (in Ukrainian).

[32] T. Oppenheimer, The Flickering Mind: Saving Education from the False Promise of Technology. N.Y.: Random House, Trade Paperback, 2003. [Online]. Available: https://www.semanticscholar.org/paper/The-Flickering-Mind\%3A-Saving-Education-from-the-ofOppenheimer /3892535d8234624bdcafcb4fc9f18ece40f02b55. Accessed on: August 10, 2020 (in English).

[33] Institutional repository of Borys Hrinchenko University of Kyiv. [Online]. Available: http://elibrary.kubg.edu.ua/. Accessed on: August 05, 2021 (in Ukrainian)..

[34] Kyiv University named after Borys Hrinchenko. [Online]. Available: https://kubg.edu.ua. Accessed on: August 05, 2021 (in Ukrainian).

[35] Facebook. Department of Ukrainian Literature, Comparative Studies and Grinchenko Studies. [Electronic [Online]. Available: https://www.facebook.com/kulk.if. Accessed on: August 05, 2021 (in Ukrainian).

[36] Facebook. Translation Center at Grinchenko University. [Online]. Available: https://www.facebook.com/pg/Translation-Centre-at-Grinchenko-University-11174217 6206968 / posts /. Accessed on: August 05, 2021 (in Ukrainian).

[37] Facebook. Ukrainian Language Culture Center. [Online]. Available: https://www.facebook.com/groups/2061838847428315. Accessed on: August 05, 2021 (in Ukrainian).

[38] Facebook. Department of Romance Philology and Comparative-Typological Linguistics. [[Online]. Available: https://www.facebook.com/romanceKubg. Accessed on: August 05, 2021 (in Ukrainian).

[39] Facebook. Flight. [Online]. Available: https://www.facebook.com/politkubg. Accessed on: August 05, 2021 (in Ukrainian).

[40] Facebook. Department of Oriental Languages and Translation. [Online]. Available: https://www.facebook.com/ks.kubg/. Accessed on: August 05, 2021 (in Ukrainian).

[41] Facebook. Department of German Philology. [Online]. Available: https: // www. facebook.com/profile.php?id=100024688208725. Accessed on: August 05, 2021 (in Ukrainian).

[42] Youtube. Competence Center «Literary Theater». [Online]. Available: https://www.youtube.com/channel/UCnzEaJoE-jicZ8DqXi-yuzA. Accessed on: August 05, 2021 (in Ukrainian).

[43] Youtube. Institute of Philology. [Online]. Available: https://www.youtube.com/channel/ UCyt0Ay3pPXF23B5eeGtf9QA. Accessed on: August 05, 2021 (in Ukrainian).

[44] Youtube. Department of World Literature. [Online]. Available: https://www.youtube.com/channel/ UCMW9QYYYy606xmPTZQQNAHw. Accessed on: August 05, 2021 (in Ukrainian). 
[45] Youtube. Student Council of the Institute of Philology. [Online]. Available: https://m.youtube.com/channel/UCnLiG3med TYQ-L2d5Fn52gA. Accessed on: August 05, 2021 (in Ukrainian).

[46] Ukrainian Language Culture Center. [Online]. Available: http://centrkum.blogspot.com/p/blogpage_17.html. Accessed on: August 05, 2021 (in Ukrainian).

[47] Telegram. Translation center. [Online]. Available: https: //xn--80affa3aj0al.xn--80asehdb/\#/im? P = @ transl_kubg. Accessed on: August 05, 2021 (in Ukrainian).

[48] Telegram. Ukrainian Language Culture Center. [Online]. Available: https: //xn--80affa3aj0al.xn-80asehdb/\#/im? P = @ kulturaukrmovi. Accessed on: August 05, 2021 (in Ukrainian).

[49] Telegram. Student Council of the Institute of Philology. [Online]. Available: https: //xn--80affa3aj0al.xn-80asehdb/\#/im? P = @ students_if. Accessed on: August 05, 2021 (in Ukrainian).

[50] Instagram. Institute of Philology. [Online]. Available: https://instagram.com/if.kubg. edu.ua?igshid=1rnnp4rbe6txjна. Accessed on: August 05, 2021 (in Ukrainian).

[51] Instagram. Department of Oriental Languages and Translation. [Online]. Available: https://www.instagram.com/ksmp_kubg/?igshid=lyvs34qjkm2e. Accessed on: August 05, 2021 (in Ukrainian).

[52] $\mathrm{Y}^{\prime}$. Korolyuk, «The influence of real-virtual educational space on the activities of the teacher», Humanities, socio-economic and social sciences, no. 11-12, pp. 158-163, 2015. [Online]. Available: https://cyberleninka.ru/article/n/vliyanie-realno-virtualnogo-obrazovatelnogo-prostranstva-nadeyatelnost-pedagoga. Accessed on: August 10, 2020 (in Ukrainian).

[53] A. Safronova, et al., «Real-virtual educational environment of the university as a pedagogical means of developing students' skills of self-preservation of health», Scientific Review. Pedagogical sciences, no. 2, pp. 32-37, 2018. [Online]. Available: https://science-pedagogy.ru/ru/article/view?id=1749. Accessed on: August 10, 2020 (in Russian).

[54] A.A. Akhayan, «Three-dimensional virtual educational space as an educational space of a networked personality», Social work: modern problems and technologies, no. 1, pp. 12-17, 2020. [Online]. Available: https://elibrary.ru/item.asp?id=42358138. Accessed on: July 23, 2021 (in Russian).

\section{$(\mathrm{Cc}) \mathrm{EY-NC-SA}$}

This work is licensed under Creative Commons Attribution-NonCommercial-ShareAlike 4.0 International License. 